\title{
Corporate Social Responsibility as a Non-Functional Norm: Its Nature and Formation Factor
}

\author{
Lyudmila Makarova ${ }^{1}$ Elena Tkach $^{1, *}$ Irina Kudryavtseva ${ }^{1}$ Anna Seliverstova ${ }^{1}$ \\ Natalya Vinogradova ${ }^{2}$
}

\author{
${ }^{1}$ Faculty of Economics, Chelyabinsk State University, Chelyabinsk 454001, Russian Federation \\ ${ }^{2}$ Department of Economics, Kostanay Social and Technical University, Kostanay 110010, Kazakhstan \\ *Corresponding author.Email: elena-tkach@yandex.ru
}

\begin{abstract}
Based on institutional approach corporate social responsibility as an institutional category is defined. The category of corporate social responsibility as a non-functional norm is suggested. Its basic features are revealed. The impact of economic, political, ideological institutions on corporate social responsibility features is researched. The conclusion on quasi-corporate social responsibility affecting factors existence of industrial environment in context of modern Russian economy is made.
\end{abstract}

Keywords: corporate social responsibility, non-functional norm, quasi-corporate social responsibility

\section{INTRODUCTION}

Actualization of the requirements for sustainable development puts forward the agenda of more balanced compliance of norms related to various institutional agreements.

Consequently, corporate social responsibility regarded to comply business interest with society interest gains special attention. Understanding of corporate social responsibility to comply business interest with the society implies institutional economics tools allocation.

Russian economy transformation started in the end of XX century was full of large-scaled changes in different society fields, fundamental changes of prior institutional system and long-term period of institutional instability. People implementing reforms were convinced that mechanism working in Western market liberal society could be successfully implemented in Russia. Nevertheless, attempts of development of a new institutional system based on Russia's background by importing some successfully operating in Western countries institutions led to unexpected results.

The process of institutionalization of business and society relations is one of cases within the issue. Therefore, implementation of corporate social responsibility in Russian context implied the way it operates in Western countries. Nevertheless, institutions of social responsibility successfully operating in the West represents just an imitation in Russia. Consequently, so-called non-functional norms appear. For example, quasi corporate social responsibility may be related to a quasi-norm. Its major feature is deliberate aid allocation to ineffective events for the society. The search for the reasons of such transformation and perspectives of institutionalization referred to relations of corporate social responsibility is one of the issues to be researched.

The research on corporate social responsibility from institutional economics perspective is of a great importance. The definition of corporate social responsibility as a norm of behaviour allows to assess its identity to functional and non-functional norm.

Analysis of publications devoted to corporate social responsibility allows to make a conclusion that positive attitude of corporate social responsibility role prevails. Therefore, corporate social responsibility is regarded as transactions costs reduction factor [1] and new clients attraction factor [2].

Nevertheless, we consider that corporate social responsibility as a norm may act as both functional and nonfunctional norm.

We defined a category of corporate social responsibility as a non-functional norm before analysing. Numerous publications of both Russian and foreign authors are devoted to corporate social responsibility. Such foreign authors as Carroll [3], Friedman [4], Moon [5], Sethi [6], Wood [7] studied theoretical fundamentals of the issue. As for Russian authors, Blagov [8], Polishchuk [9], Bataeva [10], made a research on theoretical aspects.

We suggest defining corporate social responsibility as an institutional category. Corporate social responsibility as a synthetic norm contributes to comply the interest of both business and the society by eliminating contradictions between various institutional agreements [11]. It appears as a result of a compromise between industrial, market, civil and ecological agreements and comply with public opinion. Based on the results of our research we suggest corporate social responsibility to be a non-functional norm. The following basic characteristics were developed:

- non-systematic

- involuntariness

- Pareto ineffectiveness 
The impact of industrial environment on corporate social responsibility development as both functional and nonfunctional norm has been studied.

\section{BACKGROUND}

Analysis of synthetic norms including corporate social responsibility enables to consider the existence of two types of synthetic norms: functional norms and non-functional ones called quasi-norms. Corporate social responsibility as a synthetic norm may also act as effective functional norms and non-functional quasi-norm.

It should be mentioned that the authors tending to neoinstitutionalism regard institutions from a positive perspective as beneficial rules which decrease uncertainties of the future, ease coordination and collaboration, improve people's lives. At the same time, publications made in 1990s and 2000s especially those devoted to Russian economic issues more often mention institutions as non-effective ones and use negative connotation towards it [12].

A good example of a function norm is corporate social responsibility that enables to comply business interest based on principles of dominance of norms of market and industrial agreements; authorities acts due to norms of public agreements; the society which admits norms of ecological agreement and public opinion.

The example of a quasi-corporate social responsibility is providing resources on deliberately ineffective events for the society such as alcoholic drinks festival for young people.

In order to define corporate social responsibility as effective or ineffective one, the term of effective institution should be regarded. There are two obstacles affecting the issue resolution. First of all, there is no common understanding of the nature of an institution among researchers. Consequently, it is difficult to comprehensively define what an effective institution is like. Secondly, according to a widespread definition of an institution provided by D. North [13], an institution is also a mechanism of punishment for non-compliance with norms. The assessment of human behaviour norms' effectiveness is also a complex issue.
Nevertheless, three major definitions of an effective institution might be developed based on literature. The most widespread one associates an effective institution with minimization of transaction costs. The second approach implies the assessments of institution effectiveness by its actual activities, the rate of its functions satisfaction by major groups of the society [14]. In our opinion, the third approach seems the most suitable one as it is more complex. It implies the following principles of an effective institution:

- Reduction of uncertainty of the future

- Simplification of coordination and collaboration

- People's life improvement

In case an institution meets the requirements mentioned above it refers to an effective norm type.

Let us clarify the features of an effective institution referring to corporate social responsibility. Reduction of uncertainty of the future implies a systematic nature of corporate social responsibility. Therefore, it implies organization of regular events devoted to social responsibility. Simplification of coordination and collaboration leads directly to minimization of transaction costs. The solution of the issue mentioned is possible in case of voluntary nature of corporate social responsibility. Finally, people' life improvement can be linked with actions beneficial for the society.

To conclude, corporate social responsibility might be called effective in case it is systematic, voluntary and beneficial for the society nature. In this case value for the society might imply fulfilment of Pareto effectiveness requirements. Otherwise it is a quasi-norm. Therefore, the features of quasi-corporate social responsibility are the following:

- non-systematic

- involuntariness

- Pareto effectiveness

Consequently, we have defined the features of corporate social responsibility as a quasi-norm. Let us analyse the impact of an industrial environment on corporate social responsibility development as both functional and nonfunctional norm.

The impact of industrial environment on corporate social responsibility can be illustrated by the Carroll's pyramids shown below [3] (Figure 1):

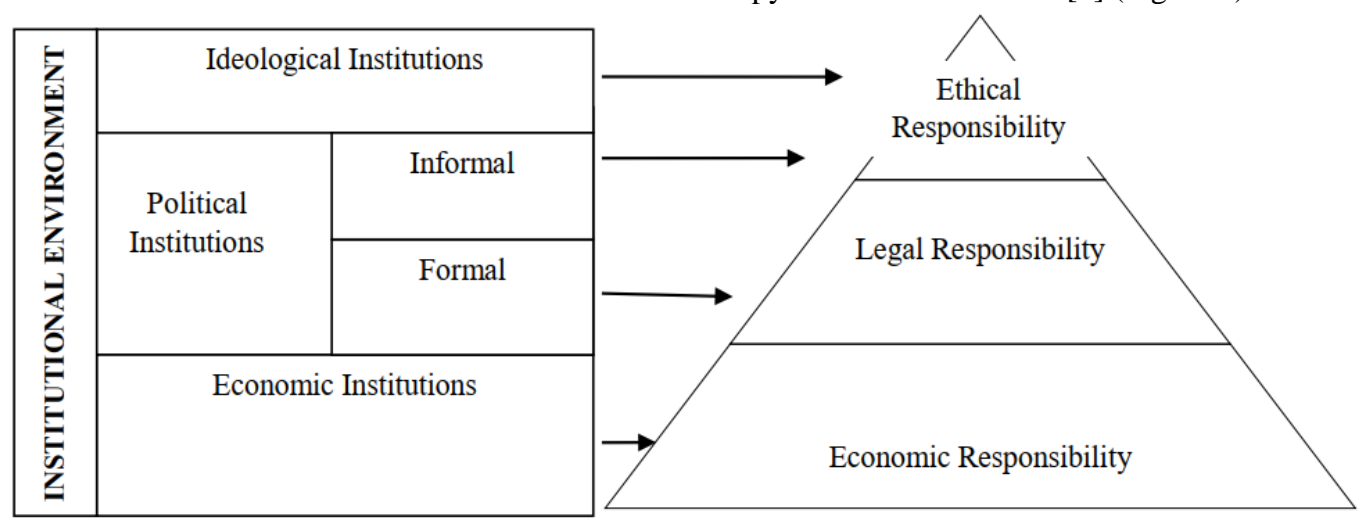

Figure 1. Impact of industrial environment on corporate social responsibility 
systematic approaches, involuntariness, Pareto ineffectiveness of corporate social responsibility because of the level of property rights security and decision-makers' behaviour. property and redistribution were revealed. The institute of superior property implies distribution of rights and property and responsibility due to hierarchical levels respectively dominated by the centre. Redistribution means the type of economic relations which implies distribution of rights and Therefore, it illustrates the distribution of quasi-corporate social responsibility (Table 1): values managed by the centre. Overall, it promotes non-

Table 1 Economic institutions and its impact on corporate social responsibility features

\begin{tabular}{|c|c|c|c|}
\hline Economic Institutions & $\begin{array}{c}\text { Corporate Social } \\
\text { Responsibility as a Functional } \\
\text { Norm }\end{array}$ & $\begin{array}{c}\text { Quasi Corporate Social } \\
\text { Responsibility }\end{array}$ & Index \\
\hline $\begin{array}{c}\text { Institution of Superior Property in Context } \\
\text { of Rent-oriented Behaviour }\end{array}$ & Not Contributing & Contributing & $\begin{array}{c}\text { Index of Civil Society } \\
\text { Development }\end{array}$ \\
\hline Property Right & Specified and Secured & $\begin{array}{c}\text { Blurred and not } \\
\text { Secured }\end{array}$ & $\begin{array}{c}\text { International Index of } \\
\text { Property Rights }\end{array}$ \\
\hline X-Effectiveness & \multicolumn{2}{|c|}{ Oriented on Internal Stakeholders } \\
\hline
\end{tabular}

Bureaucratic model of business and authorities collaboration dominating among economic actors, antirealism and civil society institutions underdevelopment were revealed among political institutions. The results of the research on it illustrates Russian economy's institutional environment predisposing nature towards quasi-corporate social responsibility development (Table 2):

Table 2. Political institutions and its impact on corporate social responsibility features

\begin{tabular}{|l|c|c|c|}
\hline \multicolumn{1}{|c|}{ Political Institution } & $\begin{array}{c}\text { Corporate Social } \\
\text { Responsibility as a } \\
\text { Functional Norm }\end{array}$ & $\begin{array}{c}\text { Quasi Corporate Social } \\
\text { Responsibility }\end{array}$ & Index \\
\hline $\begin{array}{l}\text { Business and the Government Collaboration } \\
\text { Nature }\end{array}$ & Partnership & Bureaucratic model & Corruption Rate \\
\hline $\begin{array}{l}\text { Corporate Social Responsibility Direct } \\
\text { Regulation Quality (in context of employer and } \\
\text { employee relations; ecology) }\end{array}$ & $\begin{array}{c}\text { Ratification of } \\
\text { International } \\
\text { Agreements }\end{array}$ & $\begin{array}{c}\text { International Agreements } \\
\text { Ignorance }\end{array}$ & $\begin{array}{c}\text { Agreements } \\
\text { Ratification }\end{array}$ \\
\hline Economic Actors Law-Abiding Level & High & Low & Legal Order Index \\
\hline Level of NGO Development & Contributing & Not Contributing & NGO Density \\
\hline
\end{tabular}

Analysis of an ideological institutions characterizing institutional environment of Russian economy also provide the evidence that Russian economy is predisposed to development of non-functional corporate social responsibility.

Communitarian order (public life order principles defining behavior of general public due to communitarian rules) and a widespread norm of non-personified reliance (reliable attitude towards the system itself instead of a single personality) indicates communitarian order.

\section{CONCLUSION}

To conclude, the following factors of institutional environment having impact on quasi corporate social responsibility formation were defined (Table 3):
- in context of economic institutions: Institution of superior property and redistribution

- In context of political institutions: Bureaucratic model of collaboration between the government and business, antirealism and low level of civil society development

- In context of ideological institutions: communitarian order and non-personified reliance

It seems that further research on corporate social responsibility as a functional norm might be aimed at revealing of conditions that might stimulate corporate social responsibility as a non-functional norm transformation into a functional norm. 
Table 3. Impact of elements related to industrial environment on quasi-corporate social responsibility development

\begin{tabular}{|c|c|c|}
\hline \multirow{2}{*}{ Institution } & Elements of Industrial Environment & $\begin{array}{c}\text { Indicator of Quasi-Corporate Social } \\
\text { Responsibility }\end{array}$ \\
\hline \multirow{3}{*}{ Economic } & $\begin{array}{c}\text { Institutions of Superior Property and } \\
\text { Redistribution in Context of Rent-oriented } \\
\text { Generation }\end{array}$ & Involuntariness \\
\cline { 2 - 3 } & Blurring Property Rights & Non-Systematic Nature \\
\hline \multirow{2}{*}{ Political } & $\begin{array}{c}\text { Bureaucratic Model of Business and } \\
\text { Authorities Collaboration }\end{array}$ & Involuntariness \\
\cline { 2 - 3 } & Antirealism & Non-Systematic Nature \\
\cline { 2 - 3 } & Underdevelopment of NGO Network & Involuntariness \\
\hline \multirow{2}{*}{ Ideological } & Commentivens \\
\cline { 2 - 3 } & Low Level of Non-Personified Reliance & Non-Systematic Nature \\
\hline
\end{tabular}

\section{REFERENCES}

[1] S.P. Chuang, S.J. Huang, The Effect of Environmental Corporate Social Responsibility on Environmental Performance and Business Competitiveness: The Mediation of Green Information Technology Capital, Journal of Business Ethics, vol. 150, (4), 2018, pp. 991-1009. DOI: https://doi.org/10.1007/s10551-016-3167-x

[2] G.Halkos,; \& A.Skouloudis, Corporate social responsibility and innovative capacity: Intersection in a macro level perspective, Journal of Cleaner Production, vol. 182, 2018, pp. 291-300. DOI: https://doi.org/10.1016/j.jclepro.2018.02.022

[3] A.B. Carroll, Corporate Social Responsibility: Evolution of Definitional Construct. Business and Society. Vol. 38 (3), 1999, pp. 268 - 295.

[4] M.Friedman, The Social Responsibility of Business is to Increase its Profits. The New York Times Magazine. September 13, 1970.

[5] J.Moon, The Contribution of Corporate Social Responsibility to Sustainable Development, Sustainable Development, vol. 15 (5), 2007, pp. 296-306.

[6] S.P. Sethi, Dimensions of Corporate Social Performance: An Analytical Framework. California Management Review, vol. 17 (3), 1975. P. 58-64.
[7] D.Wood, Corporate Social Performance Revisited, Academy of Management Review, vol. 16 (4), 1991, pp. 691-718

[8] Yu. E. Blagov, Corporate social responsibility: evolution of the concept.- St. Petersburg: Publishing House of St. Petersburg State University, 2015, 350 p.

[9] B.S. Bataeva, 2010. The ways of Forming Russian Model of Corporate Social Responsibility, Journal 'Izvestiâ Sankt-Peterburgskogo gosudarstvennogo èkonomičeskogo universiteta', 5: 67-72. https://elibrary.ru/item.asp?id=15278739

[10] L.I. Polishchuk Corporate social responsibility or government regulation: an institutional analysis with an appendix to Russia, Moscow: HSE, 2009. 24 p.

[11] L.I. Makarova, E.P. Makarova, Social responsibility of business as a category of institutional economics. Economic analysis: theory and practice, vol 7, 2013, pp. 37-45.

[12] G.B. Kleiner, The evolution of institutional systems. Moscow, Nauka, 2004.

[13] D. North, Institutions, institutional changes and the functioning of the economy. Moscow: Fund of the economic book "Beginnings", 1997, 180p.

[14] S.V. Patrushev, Institutionalism in political science: stages, trends, ideas, problems. Political Science, vol. 2, 2001. pp. 160-172. 